ГРНТИ 21.41 .41

\author{
${ }^{* 1}$ Aimukhambetov T.T., ${ }^{2}$ Seitakhmetova N.L., ${ }^{3}$ Yessekeyeva E.F. \\ ${ }^{1}$ Евразиский национальный университет имени Л.Н. Гумилева, \\ Республика Казахстан, г. Астана \\ ${ }^{2}$ Инстиут философии, политологии и религиоведения, Республика Казахстан, г. Алматы \\ ${ }^{3}$ Казахский национальный университет имени аль-Фараби, \\ Республика Казахстан, г. Алматы, "e-mail:timnesh@mail.ru
}

\title{
THE CONCEPT AND ESSENCE OF THE PHENOMENON OF INTERACTION BETWEEN THE STATE AND RELIGIOUS CONFESSIONS IN THE CONCEPTUAL DIMENSION
}

In this article the authors have done work on the analysis of concepts and the essence of interaction between the state and religious faiths in the conceptual dimension. One of the problems associated with the interaction of the state and religion and religious organizations of modern states is the concept and essence of this phenomenon. Despite the secularization of state and religious institutions, "the religious factor influences the economy, politics, and the state itself and society, respectively - interethnic relations, the family, into the cultural field through the activities of believing individuals, groups, organizations in these areas." Thus, there is a certain reproduction of religious relations on the background of social relations. For a deeper analysis of this topic, it is necessary to classify in more detail the concepts and essence of this direction.

Key words: Analysis, society, interaction, state, religious confessions.

\author{
1Аймухамбетов Т.Т., ${ }^{2}$ Сейтахметова Н.А., ${ }^{3}$ Есекеева Э.Ф. \\ ${ }^{1}$ L.N. Gumilev Eurasian national university, Kazakhstan, Astana \\ ${ }^{2}$ Institute of Philosophy, Political Science and Religious Studies, Kazakhstan, Almaty \\ ${ }^{3} \mathrm{Al}$-Farabi Kazakh national university, Kazakhstan, Almaty, "e-mail:timnesh@mail.ru
}

Понятие и сущность феномена взаимодействия государства и религиозных конфессий в концептуамьном измерении

В данной статье авторами проделана работа по анализу понятий и сущности взаимодействия государства и религиозных конфессий в концептуальном измерении. ОАной из проблем связанных во взаимодействии государства и религии и религиозных организаций современных государств является понятие и сущность данного феномена. Несмотря на секуляризацию государственного и религиозного институтов, все же «религиозный фактор влияет на экономику, политику, соответственно и на само государство и общество, - межнациона^ьные отношения, семью, на область культуры через деятельность верующих индивидов, групп, организаций в этих областях». Тем самым происходит некое воспроизведение религиозных отношений на фоне общественных отношений. А^я более глубокого анализа данной темы, необходимо более подробно классифицировать понятия и сущность данного направления.

Ключевые слова: Анализ, общество, взаимодействие, государство, религиозные конфессии.

\author{
1Аймухамбетов Т.Т., ${ }^{2}$ Сейтахметова Н.А., ${ }^{3}$ Есекеева Э.Ф. \\ ${ }^{1} \wedge$. Н.Гумилев атындағы Еуразия ұлттық университеті, Қазақстан Республикасы, Астана қ. \\ ${ }^{2}$ рилософия, саясаттану және Аінтану институты, Қазақстан Республикасы, Алматы қ. \\ 3əл-Фараби атындағы Қазақ, ұлттық университеті, Қазақстан Республикасы, Алматы қ., "e-mail:timnesh@mail.ru \\ Мемлекет пен діни конфессияның өзара іс-қимымдарының тұжырымдамамық \\ өлшеудегі феноменінің ұғымдары мен мәні
}

Автордың бұл дайындалған мақаласында мемлекет пен діни конфессияның өзара іс-қимы^дарының тұжырымдамалық, өлшемі бойынша ұғымдары мен мәнін талдау жұмыстары 
атқарылды. Мемлекет және заманауи мемлекеттердің дін және діни ұйымдарының өзара ісқимылдарына байланысты негізгі мәселелердің бірі осы феноменнің түсінігі және мәні болып табылады. Мемлекеттік және Аіни институттардың секуляризациясына қарамастан, бәрібір де "діни фрактор экономикаға, саясатқа және тиісіншемемлекеттің өзіне және қоғамға-ұлтаралық қарым-қатынасқа, отбасыға, дінге сенуші индивидтер арқылы мәдени ортаға, осы салаларды ұйымдастырушы топтарға әсер етеді». Сөйтіп, кейбір қоғамдық қатынастаржағдайында әлдебір діни қатынастарды тудыру белең алып жатыр. Осы тақырыпты терең та^дау үшін,берілген бағыттағы ұғымдар мен мән жайды егжей-тегжейлі жіктеу қажет.

Түйін сөздер:Та^дау, қоғам, өзара іс-қимы^, мемлекет, діни конфессия.

\section{Introduction}

As forms of public consciousness, the state and religious confessions are in constant interaction, since they have the same carriers. From this it turns out that their interaction will be carried out, while they are, part of the social life of society. This interaction takes place at two levels: structural and functional.

The concept of religion and religious confessions: All phenomena and processes that are present in a social society perform certain functions and influence the society as a whole and for each individual in particular, and religion is not an exception to this rule. Since religion has always been an integral part of the life of human society, and most of all people living on the planet consider themselves believers and profess any of the major world religions, it is only natural that the role of religion in society is very significant and the influence that renders This or that belief on the society in which it is spread is difficult to overestimate. In today's world there are many religions and religious denominations. Each of them has its own history of becoming, while remaining the most important component of society's life. The search for spiritual landmarks, points of support in the world lead to the fact that at present the role of the religious factor is growing. This is due in large part to the fact that religion is the most important social institution that includes a system of social norms, values, roles, customs, beliefs, rituals, standards of behavior.

There are many definitions of the concept of "religion". In sociological science, there are two main approaches to the definition of this concept: meaningful and functional. In the content approach, attention is given to the essence of religion. The famous French sociologist E. Durkheim noted that religion is associated with "sacred things", it is a collective activity in which a social group is involved (1). Religion is a phenomenon that unites the cultural, social and personal systems into a single organized structure that influences the processes of society's change and development. Religion is an organic part of social life, and at different stages of the development of the human society. The nature of the links between religion and society varies (1).

Religion performs a number of specific functions in society. The following functions of religion can be distinguished:

1. World outlook. Religion sets certain absolutes, by means of which the world is comprehended and an evaluation is given to society, to man, to the meaning of being.

2. Compensatory. Religion and religious faith compensate for the limitations, powerlessness of people, help to escape from the feeling of their own helplessness, relieve psychological tension.

3.Communicative. Twolevelsofcommunication can be distinguished: communication of believers with each other through religious organizations and religious activities and communication of the believer with God through prayer, etc.

4. Regulatory. Through the values, norms, traditions, stereotypes, customs, opinions, the management of the activities of individuals and groups is carried out.

5. Integrating. Religion supports the stability of this or that social factor. However, in polyconfessional societies, religion can play a disintegrating role.

6. Cultural transformation. Religion not only contributed to the development of certain layers of culture - writing, book printing, and art - but also transferred the accumulated heritage from generation to generation.

7. Legitimate. Religion can help legitimize certain social orders, institutions, relationships, norms (1).

From the above, it follows that religion fulfills certain functions and thereby occupies its own niche in society. According to Yablokov I. the terms "function" and "role" are similar, but not identical. Thus, "functions are the ways in which religion operates in a society; the role is the total result, the consequences of performing its functions" (2)..

Religion affects the state and politics, interethnic relations and the economy, society and the family 
through individuals, groups and organizations. However, the degree of influence of religion varies in accordance with the processes of sacralization and secularization. The process of sacralization (from the Latin sacer-sacred) means increasing the role of religion and religious faiths in public life, expanding the field of action and influence of religion in society, while the process of secularization is the liberation of public institutions from religious influence.

Next, consider the term religion in its sociopolitical aspect. Here the most suitable in our opinion was the study Kosichenko. Anatoly Grigorievich according to which: "Religion is a complex phenomenon of the modern world." Further, as Anatoly Grigorievich remarked, "the very term" religion "is used today in many, often dissimilar, senses." To simplify and give some framework of certainty, he distinguishes two aspects of the phenomenon of interest to us. "The first aspect is internal for religion: religion as the sphere of man's union with God, as faith, as the desire of man to save his soul for eternal life. This aspect relates only to people who believe in God, that is, to those who believe in God. is an internal matter of religion." This, Anatoly Grigoryevich believes to be the most important in religion, but at the same time "the least known outside of the intra-religious life." "The second aspect of religion is external: religion, as society perceives it, religion in its socio-political projection. This content of religion differs significantly from the intra-religious, from the essence of religion. But it is this aspect that society and the state consider to be the main, most important, most often, the only one. Therefore, when today "religion" is being said, this is precisely the second meaning of religion-religion as an element of the social structure, of public consciousness" (2).

The concept of politics: Ancient Greek philosopher Plato believed that politics is the art of living together; the sociologist M. Weber defined politics as a desire to participate in power; known German statesman and diplomat Bismarck - as the art of the possible. On the one hand, politics regulates social life, regulates relations in a socially differentiated society. On the other hand, the core of politics is power, and the desire of various social groups and individuals to participate in the exercise of power leads to the fact that the sphere of politics is the sphere of political struggle, conflicts and competition.

The concept of interaction between religious faiths and the state: The interaction of the state with religion throughout history has been quite complex and contradictory in nature, taking on a variety of forms. It was expressed in the confrontation between secular (state) and spiritual (religious) authorities for supremacy, then in their complete merging, then in their close alliance and mutual support, then in the supremacy of religious over state power, then in the supremacy of state power over the religious. The nature of the state's interaction with religion depends on many factors, and primarily on the position of religion and the church (religious associations) in society, what form of government it is, what is the legal regime of religion and church (religious associations) in the state.

Religion and religious denominations, as a rule, always played an important role in the life of society, but not always occupied the dominant position in it and their relationship with the state was not always built in the same way. Religion also plays a regulative function in society, seeking to ensure equal and peaceful coexistence of people who differ in their social status and property positions. Primitive people, confessing the cult of heaven and earth, worshiping the totems of the ancestors of the family, recognized the power of supernatural power. In many religions, for example, in Christianity, one can trace the connection between the idea of political power and the authority of the church, it is embodied in the idea of the divine direction of human affairs. For centuries, traditional Muslim states have been characterized by a complete fusion of state and church power. The head of state (caliph, padishah) was considered the successor of the Prophet Muhammad, the higher clergy played the role of political advisers, and criminal and civil law was based on religious laws - Sharia. Thus, all spheres of the life of society - family, culture, legal relations, and politics - were subjected to interference by Islam. The more significant the role played by the religious factor in the life of the country, the more strongly it influenced the relations between the state and the church.

There are two main historical types of relations between religion and the state.

The first type is divided into three directions:

1. The supremacy of state power over the ecclesiastical. So, for example, in the XIV century. On the orders of the French King Philip IV, the residence of the popes was moved to the city of Avignon, located on the territory of France, the papacy was used by the French monarchs for political purposes. This period, which lasted from 1309 to 1377, is called "Avignon captivity".

2. Subordination of the state to church institutions. In traditional Islamic states, the Muslim 
clergy performed secular functions, fully controlling the political sphere.

3. Mutual non-interference of the state and the church. This situation is typical for most countries of modern Western Europe (2).

The second type is also divided into three directions:

In secular states, the interaction of the state with religion is characterized by the fact that all types of religious organizations are separated from the state. For the legal regime of religion and church in a secular state (it is usually called the separation of church and state), the main thing is the following:

1. no religion can be established as a state or compulsory religion;

2. The state has no right to control the attitude of its citizens towards religion;

3. Religious associations are separated from the state and are equal before the law;

4. The state regulates the activities of religious organizations, exercises control over them, but do not interfere in their internal activities, if the current legislation is not violated;

5. The state does not render any of the faiths either material, financial, or any other assistance;

6 . The state protects the legitimate activities of religious organizations, ensures their equality before the law, proclaims and legally secures freedom of conscience, freedom of religion, including the right to profess any religion or not to profess any, freely choose, have and disseminate religious and other beliefs and act in accordance with them;

7. Religious organizations cannot participate in the political life of society, interfere in the affairs of the state and perform any state functions.

At present, the separation of church and state and the status of a secular state are, as a rule, fixed in states with a republican form of government (the Russian Federation, Germany, France, etc.).

In clerical states, the state's connection with religion and religious organizations is characterized by the regime of state religion and the church. This mode is shown in the following:

This or that religion officially has the status of state and occupies a privileged position in comparison with other faiths;

There is close cooperation between the state and the church in various spheres of public life (for example, in the upbringing of the younger generation);

For the church, the state recognizes the ownership of a fairly wide range of objects (land, buildings, structures, objects of worship, etc.);
The church receives from the state various subsidies and material assistance, tax incentives;

The church is endowed with a number of legal powers (mainly in the field of marriage and family relations);

The church has its representation in state bodies, as well as the right to participate in the political life of the country.

In clerical states, despite the existence of state religion, the merger of the state and the church, however, does not occur. It is believed that the declaration of a particular religion state, indicates the respect of the state religion, professed by the majority of the population. To the clerical states now belong Great Britain, where the official state church is the Anglican church, headed by the queen, Denmark, Norway, Sweden and some others.

In theocratic states, the connection between the state and religion is the closest. There is often a complete merger of the state with religion. In the literature, the following features of a theocratic state are noted as essential:

State power belongs to the church and the state thus acts not only as a political entity, but also as a religious organization;

The head of state, as a rule, is simultaneously the highest religious figure, the supreme clergyman, in whose hands considerable powers are concentrated;

There is a strict centralization of the state apparatus, there is no separation of powers;

The creation of political parties is generally prohibited (Bhutan, Iran, Nepal, Saudi Arabia);

There is a primacy of religion over the law. The regulation of the main aspects of public life is carried out by religious norms, which, in fact, are the law;

Theocratic states include Iran, Morocco, Pakistan, Saudi Arabia, and others.

Finally, atheistic states, as well as secular ones, are inherent in the separation of religion and church from state. However, here the interaction of the state with religion and the church often acquires hypertrophied forms: religious organizations are either banned or, in one way or another, persecuted by the authorities.

The interaction of atheistic states with religion and the church is usually expressed in the following:

Religious organizations are either prohibited or under strict state control;

The church is deprived of an economic foundation - its property;

Religious associations are not legal entities and cannot perform legally significant actions;

It is prohibited to conduct religious sermons, religious rites and rituals in public places; 
It is prohibited to publish and distribute religious literature;

Often, in relation to priests and even believers, the state applies repression;

Freedom of conscience is often reduced to the freedom of propaganda of atheism.

The state of militant atheism was the Soviet Union (especially in the early years of its existence), as well as some socialist countries. For example, in the socialist Albania, the Constitution of 1976 in general prohibited all religions.

In the first case, despite the legal securing of secularism and "with formal distancing from religious associations and declaring legal equality in the legal field of all religious organizations, the state, as practice shows, can tolerate and even support certain activity of confessions with historical and cultural roots in life peoples, this country» (3).

The need for a comprehensive study of the relationship of such social institutions as religion and politics is due to the fact that the study of these spheres of social relations is important for creating a secular society with truly humane principles and a rich spiritual base. This is necessary for the ability to confront modern threats, both political and religious, and cultural and economic.

In modern Western society, the state and religion coexist parallel to each other. Religion promotes the substantiation and maintenance of public values, including political values, which affects the attitude of society towards law and authority. Church institutions can represent the interests of individual social groups, contribute to the strengthening of their influence. Religious organizations take part in the political process through active ideological activity. This relationship between religion and politics is conditioned by the fact that for most people religious faith is part of national culture and is inseparable from the way of life and the foundations of the socio-political structure of society.

In the modern world, we can talk about three main forms of interaction between religion and politics:

First, the use of religion for political purposes. For example, in 1991, Iraqi leader Saddam Hussein motivated the attack on Kuwait by the fact that the Kuwaiti royal family does not behave in accordance with the norms of Islam.

Secondly, the influence of religion on politics within the framework of legally established or generally accepted procedures. In Western Europe, the church seeks to influence legislation through generally accepted democratic channels. In countries such as Spain, Portugal, Italy, the church argues with the state on issues of family and education.

Third, about the sacralization of political institutions. An example is Japan, where the national religion - Shinto - is the spiritual basis of Japanese political institutions.

In the modern world, religion still continues to perform functions similar to the functions of ideology, which leads to its politicization. However, this does not always mean that society is becoming more religious. Very often, especially in third world countries, dissatisfaction with socio-economic or political realities is expressed in the form of religious unrest aimed at achieving some kind of higher justice. In these cases, religion can be an alternative to such modern ideologies as conservatism, liberalism or socialism. As already mentioned above, religious faith is an organic part of national culture. The processes of globalization, which often contribute to the Westernization of traditional societies, can lead to an increase in the tendencies of nationalism that contribute to the preservation of an original culture; religion in such cases becomes an important part of nationalistic programs.

These features of social development lead to the fact that the religious factor increasingly plays an important role, both in internal and in international conflicts. What is the basis of such phenomena as medieval Crusades or terrorist acts of modern Islamic fundamentalists? At first glance, the basis for these aggressive acts is religious faith.

Does this mean that religion initially contains norms and regulations calling for violence and expansion? World religions, i.e. Buddhism, Christianity and Islam in their classical version, are based on tolerance and philanthropy; they do not call for direct struggle against dissenters. However, religion and the church have special opportunities to influence the worldview and conduct of believers. The interpretation of the divine covenants is the monopoly of the clergy, and such a monopoly often leads to the fact that the greatest attention is paid to one dogma to the detriment of others. For example, Islamic fundamentalists use the concept of jihad to refer to war with infidels in the name of spreading the Muslim faith. However, from Arabic, jihad translates as «effort». If in the first centuries of the spread of Islam jihad was really treated as a war, and the war is defensive, then since the XIV century. The concept of jihad becomes more complicated: the highest manifestation is jihad spiritual, that is, inner self-improvement on the path to Allah.

Thus, jihad can also be interpreted as the justification for the application of maximum efforts for the prosperity of the state, and as an excuse for 
terrorist attacks - it all depends on the political tasks of one or another leader.

There are three types of state relations to religion: the transformation of state power into the center of religion (caesaropapism);

subordination of the state to church institutions (papocezarism);

Union of the state with the church (3).

Papocezarism is the situation in which the patriarchs of the church have the opportunity to manage the affairs of the secular government. In the most vivid form, Papocezarism was characteristic of medieval Western Europe, where the Catholic Church largely determined the political situation in it, although not always, as evidenced, for example, by the Avignon captivity of popes. Under caesaropapism is understood the phenomenon, when secular authorities have an excessive influence on the church, especially when they are trying to determine its dogma. Religion in some cases can perform an organizational and political function, motivating political actions, forming an ideology and contributing to the creation of political doctrines.

No less striking proof of the influence of Religion on the political and legal reality is the existence of religious legal systems: Hindu, Judaic, canonical, Muslim law. Scientists' comparativists of both the past and the present even subdivide even the legal systems of countries by the criterion of religious orientation. The authors of the encyclopedic reference book on the legal systems of our time in 67 out of 103 countries indicate that the confessional composition of the population influences the nature of the national legal system (3). According to other scholars, even the existing fundamental acts on human rights have experienced religious influence. Thus, the teachings of J. Maritain, the most prominent representative of the neo-ThomismDoctrine of Natural Law - was one of the concepts that ideologically prepared the development of a universal declaration of human rights (4).

Today it is difficult to find a country where only religious law is oriented. Almost everywhere, in the total volume of legal, not those that are recorded in religious sources and based on the principle of divine origin are distinguished, but created by legislative, executive or other state bodies. This is typical even for countries where Muslim law is applied - the most common religious and legal system of our time. It is another matter that when interpreting or applying secular norms, it is often necessary to be guided by religious norms and religious sense of justice (4). Perhaps one of the basic features of the stage of development of modern political and religious relations is secularization. Here, under secularization, the process of repressing the religious and mythological world outlook of mankind, and the related weakening of the authority of religions into areas of activity that previously undoubtedly belonged only to religious institutions: culture, education, art, politics, even economics fell into the sphere of influence of religion, etc.

The explanation of the cause of such processes is known to us from the scientific works of Garadzhi VI, in his opinion "religion is changing, it is important to note that," it undergoes large and smaller changes over sometimes small time periods, "somehow, such changes are noticeable for one generation. However, according to Garadzhi VI. "Changes can also be long-term," and stretch for centuries. Religion, as everyone knows, in contrast to other spheres of consciousness is more conservative. Each religion, in one way or another, "claims to have a divine revelation," in other words, to possess eternal truth. If the world, society and the person himself and his experience are subject to change, then religion needs to change with the times, otherwise, there will be "alienation of religion from what people live from their real interests and needs" (4). Despite the fact that the constitutional principle of the secularity of modern states presupposes the dissociation of the political system from religious, state power from religious organizations, in fact such a process is not possible to produce completely. Despite the different purposes, objectives, spheres of activity of religion (the sphere beyond natural, spiritual life, power relations, and management of social strata, society and state) are invariable.

Religious teachings often use political terms and categories (kingdom, king, slave, lord), which are filled with sacred content, and serve to illuminate or discredit earthly politics, power, etc. ("There is no power not from God", "King is the anointed of God", "Prince of this world - Satan"). In some religious systems there are ideas about the coexistence of two levels of political life (the "two Grades") heavenly and earthly, in others the political life is not separated from religious (Islam) (5). A number of churches and religious figures regard politics as not a godly, immoral affair, others argue that religion does not oppose politics, but is called to help bring the righteous to power, to rid the public life and power structures of ruling sinners and atheists. Political structures are dragging into the sphere of their activity, folding religious institutions (5).

In the ancient world and medieval religion becomes an integral part of the state apparatus. Priests usually did not resist this, because they had 
their own economic interests. As a rule, priests and church structures were large landowners, had at their disposal slaves, serfs, and various kinds of wealth. Often the church was kept in the hands of the authorities, receiving political and other support from the state, including in the struggle against the opposition and heresies in the church itself (5). With the onset of the era of modern states, world religions have constantly sought to subordinate the influence of the population of entire states and regions of the world, and in this they have succeeded sufficiently. It is not by chance that such concepts as Christian Europe, Orthodox Russia, the Muslim East, the Holy Land (Israel), etc. arose. In many cases a certain religion, or one of its directions, was subordinated to the state authorities or concluded with them written or unwritten concordats (agreements) about the socalled established church. In turn, the supreme rulers declared themselves patrons or heads of the respective churches, and sometimes appropriated to themselves and the main clerical order, abolishing the supreme religious authority. Such situations existed for a long time in the relations between the British Crown and the Anglican Church, the Imperial Authority and the Orthodox Church in Russia. These issues all the more require careful consideration that each society, the state in its own way, interprets differently and, most importantly, carries out practical actions in the sphere of the relationship between religion and politics. That is why only a thorough and objective study allows us to understand what caused these different interpretations and actions, how they are actually democratic. For example, without taking into account the religious factor, it is difficult to understand the background of a number of political actions observed today in certain countries, regions, and even in the world, there are acute socio-political disasters (for example, in Latin America, Northern Ireland, India), up to hostilities Iraq-Iran), where as the leading cause (at least on the surface of events) are religious motives (6). Moreover, the very essence of a number of socio-political movements in some regions of the planet cannot be understood without taking into account the peculiarities of their ideological religious frameworks. The practice of the socio-political movements that are unfolding today, connected with religion, again confirms the long-standing contradictory tradition. The social effect and political consequences of their activities are not the same, sometimes even opposite. Here, too, is the connection with the ruling classes, the sanctification of class inequality, social oppression and the development of liberation movements, in a specific form expressing certain aspirations of the masses. Of course, this is due to the fact that religion has a broad interclass basis; as a rule, its adherents belong to opposing social groups, class forces (6).

It should be noted that the democratic liberation movement often guided by unscientific illusory programs. Handling radical possessing certain revolutionary democratic potential segments of the population to the seriousness of the problem of religion exacerbates the relationship between religion and politics, makes it necessary to in-depth and comprehensive review. Therefore, the point is to objectively identify the real function of religion in political movements, the real political and ideological sense of the modern increased activity of various circles and trends in religious organizations.

Of course, more widespread cases of this phenomenon have been observed in the past. Suffice it to recall the anti-Catholic movement in Europe in the 16th century - the Reformation, which was an important stage in the struggle of the bourgeoisie of a number of European countries against feudalism. All the forces participating in the Reformation movement (burgherism, part of the nobility, seeking to limit the power of the church and appropriate its land holdings, the peasantry) raised the religious banner, speaking at the same time with certain political demands. For European history, the Reformation was, one of the most characteristic revolutions in religious dress (6).

If you look at the processes taking place in modern world politics, one can notice one important fact, the role of the religious factor is actively growing. Opinions in this case are divided, one perceives such information as the growth of religiousness of society, a return to spirituality, and others may notice that in able hands, religion is an effective tool for imposing an alien ideology and involving the masses in political games of a radical nature. From this it follows that today religion and politics are firmly bound by an indissoluble goal. The reason for this symbiosis is various objective and subjective grounds. If we recall the events that took place on January 21, 2014 in Kiev (Ukraine) on Grushevskogo Street, three priests with icons and a cross stood between the warring parties, as the father of the Protopriest Nikolai Danilevich noted, the "fathers prayed for the cessation of confrontation" (7) between the protesters and representatives of state power.

Obviously, in order to understand the entire system of such interweaving, it is necessary to have in-depth analysis and comprehensive political science, sociological and directly religious studies. This will allow us to reveal not only the common 
causes of the symbiosis of politics and religion, but also historical features, certain conditions for the origin and development of the process under investigation, in the sphere of which we have the opportunity to observe their mutual relations. Religion and politics for many centuries, one way or another, come in contact and touch each other. At the same time, the degree and nature of the influence of the religious factor on politics are different, but its presence in political actions and movements is by no means an accidental phenomenon. And this is due to the essential characteristics of both religion and politics (7). Religion invariably rests on a fairly large mass of its followers. This is a form of social consciousness. In certain historical periods, in certain regions of the planet, this is a form of consciousness, the most widespread among the masses, and sometimes it dominates all other forms of social consciousness. Therefore, in all cases when it comes to religion, the question concerns more or less significant people $(7$, p. 38). Being connected with class interests, with the problem of power, politics, in turn, begins when it comes to certain social groups, classes, and nations. Politics, therefore, is also inevitably connected with huge masses of the population [8, p. 159]. Hence, it is not difficult to conclude from this that if the objects and carriers are essentially the same, then religion and politics must inevitably overlap. Both history and modernity convincingly show that it was so, so it is. Consequently, for a long time the fates of the two phenomena of social life under consideration will be crossed, or even more precisely than, as long as they exist. Therefore, it is important to approach this problem in a sober and realistic way, avoid meeting with politicians and religions any haste, unreasonable desire to get rid of the "annoying" combination as quickly as possible, as well as any underestimation of this phenomenon.

In the process of the historical development of mankind, religion was involved in political and social relations, since it is capable of affecting both the individual and society as a whole. The consequence of this is the close relationship of religion and political power, because political power is achieved and maintained through coercion, or influencing the ideology of the society and the spiritual worldview of man. Currently, the ideological manipulation of the public consciousness, not only rooted, but also has a tendency to grow. Often a tool in manipulating public consciousness is religion, because it is an ideology and a system of social institutions, and these spheres of public life are somehow connected with the state (8). Political interests and moods contribute to uniting and dividing people. State power compels citizens to obey and relies on violence. It has for this purpose a law enforcement system, an army, a state apparatus and other powerful tools for imposing its will and suppressing possible resistance. The common between them. For politics, purely "secular", power interests and ueli, have a self-sufficient significance, they are specific in each country and region $(8$, p. 154).

Unlike religion, politics is permeated with momentary calculations, the strategy and tactics used in it reach the heights of science and art. Politics is pragmatic in nominating exclusively terrestrial short-term, medium-term and long-term goals. Long-term goals are carried out in it with a variety of sophisticated and often unscrupulous means such as recruiting and persuading allies, persuading waverers, intimidating and suppressing opponents, espionage, demonstrating force, misinformation, information leakage, manipulation of public opinion, etc. $(9$, p. 478). The politician's motives are dominated by religious motives. The logic of confrontation dictates strict rules of conduct, often makes it necessary to mask its real intentions, resort to cunning and other, condemned religious moral devices and means $(9$, p. 78$)$. If politics is based on violence, then religion usually condemns violence. Religion demonstrates the priority of "heavenly" in relation to "earthly", "sacred" - to "profane," spiritual - to the physical and material. The religion is clearly dominated by the moral principle, the clergy usually cares about the authority of the church and avoids direct participation in political actions risky for its reputation. However, in history one can see religious processes of political significance and political processes taking place under religious slogans (9, p. 124). Therefore, first of all, it is necessary to take into account the specific content of religious subjects, ideas and slogans with political content, as well as religious design of specific political actions. The combination of religious and political factors found and finds expression in such phenomena as religious wars (Crusades, Jihad, etc.), religious pacifism (rejection of war for religious reasons), in other phenomena of religious and political life.

The authorities involve the church in politics primarily because it has a huge spiritual impact on citizens, have information about them and strong levers of psychological influence and can influence the attitude of the subjects to power. History shows that in many countries the appeal for spiritual support to the church consolidated state power. But usually the church in the state life obediently obeys the established legislation and its 
cult and extracurricular practice is included in the mainstream of state policy. Politicizing the activities of the church forces it to obey the rules and logic of political behavior. Often the ruler was proclaimed a descendant of the gods or deified. This is enshrined in his title. So, in Shintoism, the Japanese emperor was considered the son of the sun goddess Amaterasu. On this basis, the cult of the monarch is formed (the cult of the pharaoh in Egypt, the cult of the emperor in ancient Rome). The so-called "cult of personality" (the cult of Napoleon, the leaders in the socialist states, etc.) has become a kind of secular reproduction of the centuries-old religious tradition. Religious ideas, like religion in general, are actively used even in the most unsightly acts of secular power, which contradict the very nature of religious life. In fact, it is in this connection that the spiritual leaders, the politicized clergymen, are mired in intrigues, thereby leaning toward such more characteristic concepts as lies, hypocrisy, corruption, etc. The events in the neighboring Republic of Kyrgyzstan, where the names of supreme muftis often come up in various crimes of political content.

A typical situation in history is the subordination of the church to the dominant authoritarian regime. However, history provides vivid examples of confrontation of devotees of faith with political actions that contradict religious beliefs. For example, Metropolitan Philip courageously denounced the oprichnina and other crimes of Ivan the Terrible. Separation of church and state, noninterference of secular authorities in its activities is a necessary guarantee of protection of religion from politicization. The participation of the confession in peacekeeping activities, environmental movements, in charity, and their contribution to the civil consolidation of society are organically coordinated with the spiritual and moral purpose of religion [9], which also separates the political structure from the religious sphere.

In this context, we are interested in the point of view that exists in modern sociology, relating to the process of secularisations, advocated by supporters of phenomenological and cultural approaches, such as P. Berger, T. Lukman, T. Parsons, C. Tylor, etc. According to their opinion, the decline in the role of the church, at this point in time, does not mean that religion has left the public consciousness. We are inclined to their opinion that in today's world it is necessary to speak not about secularization, but about the emergence of the hypothesis of "religious transformation". This hypothesis asserts that secularization and cultural shifts like the growth of individualism and social disintegration do not lead to the disappearance of religion, but to an increase in the attractiveness of more individualized religious and spiritual practices. It is significant here that as such religion is prevalent in most cases among rural residents or lagging behind in development states. Nevertheless, religion does not disappear in the secular developed states, it has been transformed into a new form of public consciousness, an important argument in which is the individual choice of religious practices made by man. A person can become spiritual, but not religious or simply support religious institutions and religious practices performed by other people[8]. The principles of the secular state provided by the Constitution of modern democratic states guarantee the separation of the religious sphere from the state, which makes it possible to clearly delimit the spheres of activity, competence and influence of the state structure and representatives of confessions, which in turn is the cause of the relationship between politics and religion on the basis of responsibilities. According to M. Shakhov, this kind of "differentiation of spheres of competence does not mean" the displacement of religion from the life of society, and certainly does not mean "the removal of religious associations from participation in solving socially significant tasks." $\mathrm{He}$ further adds that "the state, following the principle of equality of religious associations before the law, creates for them a common legal field" within which religious associations have equal opportunities for their activities. Here he notes that "at the same time, a different degree of cooperation between the state and different confessions is allowed." Such cooperation is due to various reasons, it can be historical, or can be expressed in the social position of a particular confession, and certainly the number of "followers of this religion in the country and in the world, etc., are of no small importance. » (9). From the analyzes carried out by Gallup International experts, one can draw a conclusion, again confirms the hypothesis popular in the theory of secularization: "poor countries are more religious than rich, and" educated "are less religious than" uneducated» (10). This version is not groundless and easily verified which is especially noticeable against the background of the poorest countries. Making such studies, it is always necessary to take into account the political, cultural, historical, demographic characteristics of a particular state for which a secularization process is characteristic. Comparing the Protestant states of Europe with the Catholic, one can consider the following features: in Catholic countries, religiosity is higher than in Protestant ones Protestant countries are often richer than Catholic ones, which is 
also natural, proceeding from M. Weber's work "Protestant ethics and the spirit of capitalism". But religiosity is due nevertheless to the cultural model of the Catholic countries. Religious features of Western Europe can be understood on the basis of historical features of the relationship between religious and state spheres, while taking into account the processes of secularization in each of the states. Important is the fact that religion still occupies a special place in the life of modern society, while the influence of religion is different depending on each individual. On the level of religiosity of a modern person, it is largely not political instruments, but independent acceptance of spirituality, or alienation of religion at all. Often, religion is nothing but the defining moment of self-identification, this is also facilitated by various political and interconfessional relationships. From the process of secularization, religion has been removed from politics, but remains one of the influential institutions of modern society, with its own tasks, goals and challenges.

Thus, it can be concluded that the interaction of the state and religious associations involves a number of difficulties from almost all spheres of public life, and only competent joint mechanisms for coordination and interaction of the state and religion can become a way out of the current situation in the country.

\section{References}

Printsipy demokratii v Islame// novoe delo. 16.05. 2003. № 20.

Mukhametshin F.M. Vzglyad na islamskii fundamentalism. - M.: - 1998. - 31 s.

Ignatenko A.A. Endogennyy radicalism v Islame // Tsentralnaya Azia i Kavkaz. 2000. № 2. - S. 2-12.

«Islam memleket» v razdele «Ekonomika zhuesi». Rotopritnoe izdanie

Miroshnikova E. Gosudarstvenno-tserkovnye otnosheniya v Germanii // Religia I pravo. 1988. - №1-2. - S. 45-47.

Zakon «O religioznoi deyatelnosti i religioznykh obedeneniyakh»/ Almaty: «Yurist», 2013.

http:/www.neonomad.kz/styleneonomad/moda/index.php?ELEMENT_ID=3842.

Obshchestvennoe obedinenie «Izgi amal». Manifest Islamskoi reformatsii. TOO «Mag-Nur». 2009 g. - 104 s.

Orynbekov M.S. «Genezis religioznosti v Kazakhstane» - Almaty, 2013 